\title{
A Chronicle of Frustration and Final Vindication: International Legal Advice in Spain and the Iraq War (2002-2003)
}

\author{
Juan Antonio YÁÑEZ-BARNUEVO*
}

\section{INTRODUCTION}

The Iraq crisis of 2002-2003 is an excellent case study in the importance of providing expert advice to decision-makers on crucial international legal issues related to matters of war and peace - and also in the limitations and frustrations involved in such an endeavour. One is reminded of the title of the famous novel by Alfred de Vigny: Servitude et grandeur militaires (1835). To stretch the comparison somewhat, the way things played out inside the Spanish Foreign Ministry in this specific case could also be deemed a good example of the "servitude and greatness" of diplomatic legal advice. Let me explain why.

In July 2002, I was tapped by the then Foreign Minister to become Head of the International Legal Office (Asesoría Jurídica Internacional, AJI) in the Spanish Foreign Ministry, where I had already worked in the late sixties and mid-seventies. Despite its grand name and important responsibilities, the AJI was - and still is - a very small unit, comprising a mixture of diplomats and academics, all of them versed in international law and experienced in foreign affairs. Nevertheless, the Office's wellearned reputation within the Ministry, and even beyond, in no way ensures that its advice will always be heeded, or even listened to at all. As will be shown in this paper, this was unfortunately the case in this particular instance.

\section{THE LEAD UP TO THE CONFRONTATION}

By the time I assumed the post of Head of the AJI, it was apparent that a serious crisis was looming over Iraq. At first, this was due to the repeated failure by the Iraqi regime of Saddam Hussein fully to abide by its obligations under the ceasefire reached at the end of the Gulf War (199I) and, more specifically, under the provisions of the famous United Nations Security Council (UNSC) Resolution 687 (199I) - "the mother of all UNSC resolutions" - which set harsh conditions on Iraq, including strict controls on the disarmament of weapons of mass destruction (WMDs) and mid- and long-range ballistic missiles. For several years, Saddam and the international community had been playing a game of "cat-and-mouse". Despite the ups and downs, there had been an undoubted measure

\footnotetext{
* Ambassador of Spain. Head of the International Legal Office, Spanish Ministry of Foreign Affairs and Cooperation (2002-2004).
} 
of success in some relevant areas; however, by the end of the decade, the process had reached an impasse. The whole matter, until then treated as a question of containment of a serious regional nuisance, acquired a new dimension after the grave terrorist attacks of II September 200I in New York and Washington, when the Bush Administration, not content with the US-led armed intervention in Afghanistan to oust the Taliban regime and disperse the Al-Qaeda leadership it hosted, set its sights on Saddam Hussein as a supposed mastermind of international terror, as well as a suspected cheater in the area of WMDs. The objective of cornering and eventually confronting Saddam was made crystal clear in the speech that President Bush made at the high-level opening of the UN General Assembly (UNGA) session on I2 September 2002 - not by mere coincidence, just one year after the terrorist attacks on the most important US cities. This was coupled a week later with a formal request by the US President to Congress to approve the possible use of force against Iraq should its regime fail to fully bow to the demands of the international community.

\section{FIRST OPPORTUNITY TO GIVE LEGAL ADVICE BEFORE THE CRISIS}

In late September 2002, the AJI received a request from the office of the State Secretary for Foreign Affairs to provide written advice on the international legal aspects of a possible armed action against Iraq, as envisaged in discussions going on at the UN and in various capitals. It was a very generic request with no added specifics, so that the AJI had to work with its own means, quite separately from whatever deliberations were going on at the political level in the Ministry. At the time, this operating procedure had clear drawbacks, but it ultimately proved to be beneficial for the AJI because it could then act with complete independence, free of any political pressure or contamination. Given the importance of the matter, as Head of the AJI I undertook the task of writing the report, but before completing it I consulted with all of my colleagues in the Office, who fully concurred in the analysis and conclusions of the draft, while also making some suggestions that were incorporated in the final version. The detailed final report, dated 8 October 2002, was sent to the office of the State Secretary and also to those of other high-level decision-makers in the Ministry.

The report reviewed the essential features of modern international law on the use of force as they applied to the case of Iraq, successively covering: the principle of the prohibition of the use of force in international relations and its exceptions; the right of individual or collective self-defence (including the question of so-called "preventive self-defence"); recourse to force in the framework of the UN collective security system (with an examination of relevant decisions by the UNSC in the case of Iraq, including the issue of whether the original authorization to use force was still standing or could be reactivated and how); and the objective and purpose of a possible international armed action against Iraq (including the question of so-called "regime change"). In this detailed examination, the report based its analysis on the relevant provisions of the UN Charter (in particular, Article 2, paragraphs 4 and 7, as well as the whole of Chapter VII, above all, Articles 39, 42,5I and 53); the Declaration on Principles of International Law Concerning Friendly Relations and Co-operation among States (UNGA Resolution 2625 of 1970) and the Declaration on the Inadmissibility of Intervention in the Domestic Affairs of States (UNGA Resolution 213I of 1965); the relevant jurisprudence of the 
International Court of Justice, especially its judgment in the case of Military and Paramilitary Activities in and against Nicaragua (Nicaragua $v$ United States), Merits (1986), and its advisory opinion on the Legality of the Threat or Use of Nuclear Weapons (1996); the diplomatic precedent set on the occasion of the Caroline incident (US/UK, I842); the relevant UNSC practice regarding other situations concerning international peace and security (as in Korea, the Congo, South Rhodesia, Haiti, Afghanistan, etc.); and the series of UNSC decisions on the Iraq crisis since the invasion of Kuwait, especially Resolutions 678 (1990), 686 (1991), 687 (1991) and 949 (1994).

On the basis of this thorough analysis, the AJI reached a number of conclusions in its report, which can be summarized as follows:

I. The UN Charter and general international law only recognize two lawful bases for the use of force in the international sphere: either in the exercise of legitimate self-defence against an armed attack or with the explicit authorization of the Security Council under Chapter VII of the UN Charter.

2. As the circumstances presented themselves at that time, there were no valid grounds for a claim of self-defence, as Iraq - unlike on previous occasions - had not recently engaged in hostilities with any other State, none of its neighbours was claiming to have been attacked, and there were not even signs of a real and imminent threat that Iraq might soon be engaging in any such attack.

3. The question of Iraq and, particularly, the international control of its obligations concerning any WMD programmes was an issue that concerned the UNSC, which was actively seized of the situation and acting on it. It was thus for the UNSC to take any decision on the matter, including the possibility of adopting any further coercive measures under Chapter VII of the Charter, such as the possible use of force as a last resort.

4. As to the view that the original authorization to use force, adopted by the UNSC in 1990 to coerce Iraq to leave Kuwait, could be said somehow to remain in force under the terms of the ceasefire and Resolution 687 (199I), again it was a matter for consideration by the UNSC, which could "revive" that authorization in various ways, and was not subject to a separate decision by any individual State or group of States.

5. Finally, the purpose of any hypothetical international armed action against Iraq could only be to force its regime strictly to comply with its obligations towards the international community; it could not include so-called "regime change" unless the relevant UNSC decision clearly pointed in that direction.

\section{A STRANGE INTERLUDE}

Quite surprisingly, given the importance of the subject matter and the clear conclusions the report contained, it did not elicit any reaction from its recipients - at least, so far as the AJI was concerned. No request for clarifications, no invitation to take part in any discussions, no rebuttals of any kind...; nothing came from the Ministry principals for some time. Then, after UNSC Resolution I44I on Iraq was adopted on 8 November 2002, I received a brief communication from the office of the State Secretary tersely asking the AJI whether the new resolution affected in any way the conclusions of our earlier legal opinion. 
Of course, we examined the content of the important new resolution carefully, especially the stern warning to the Iraqi regime reflected in its last few operative paragraphs. I was ready to start writing a report explaining why Resolution I44I, though it certainly opened a new chapter in the long history of UNSC decisions concerning Iraq, neither contained an explicit authorization to use force nor could be considered by itself as "reviving" the old authorization of 1990-I99I, when I received another communication from the same source telling me that "it was not necessary" for the AJI to produce the fresh report that had been requested. I was certainly sorry to receive this counter-order, because it deprived the AJI of the opportunity to give its considered opinion on an important question, but there was nothing I could do about that, as the relevant rules clearly state that the AJI can only issue opinions on request by the competent Ministry authorities, never on its own initiative. It already seemed clear by then that those at the political level in the Department preferred not to feel encumbered in this matter by an expression of legal advice that probably would not be in line with their policy preferences.

\section{A SECOND OPPORTUNITY FOR LEGAL ADVICE IN THE MIDST OF THE CRISIS}

The next stage of the AJI's involvement in the Iraq issue came several months later, when the UNSC (to which Spain had acceded as a non-permanent member beginning on I January 2003) was discussing - quite heatedly - the appropriate course of action to take regarding Iraq, following the first reports of the international WMD inspectors (from UNMOVIC and the IAEA), with whom the Iraqi regime had finally agreed to cooperate after the adoption of Resolution I44I. In late February 2003, the AJI received a new request for advice - this time from the UN Affairs Directorate- which was more focused in scope and more precise in its presentation than the previous one, but was still quite relevant and consequential. The request concerned the relationship between UNSC Resolutions 1284 (1999) and I44I (2002), both relating to the international supervision of Iraq's WMD programmes, in light of the discussions going on at that time in the Security Council. In fact, two distinct approaches had emerged within the Council, embodied in separate documents, both dated 24 February 2003: on the one hand, a memorandum submitted by France, Germany and Russia, which favoured the continuation of reinforced inspections according to a clear programme of action with a strict timeline and sustained pressure on Iraq; and, on the other, a draft resolution proposed by the US, the UK and Spain, which in effect was intended to open the way for a possible joint armed action against Iraq if the Iraqi regime did not fully and unconditionally comply with its international disarmament obligations and the UNSC demands.

Again I took up the task of writing the report, taking advantage, among other things, of my own experience leading the Spanish delegation in the UNSC during the period 1993-1994 in which the question of UN control of Iraq's WMD programmes had figured prominently. The AJI report, dated 3 March 2003, examined the two relevant UNSC resolutions (plus several others related to them) and, after a textual, contextual and teleological analysis, reached the following main conclusions:

I. Both UNSC resolutions were relevant and applicable to the matter at hand; in fact, it was clear that Resolution I44I built on Resolution I284 (which, among other things, had created 
UNMOVIC for the purpose of controlling Iraq's WMD programmes), a point shared by both the memorandum submitted by France and others and the draft resolution proposed by the US and others, even if they reached very different conclusions as to the way forward.

2. The main point of contention concerned the question of the respective timelines contained in each resolution for the Iraqi regime to comply with its disarmament obligations, for the international inspectors to perform their work, and for the UNSC to examine their reports and take appropriate decisions at each stage, one way or the other (that is to say, by pursuing disarmament inspections and possibly alleviating previously imposed sanctions if Iraq effectively cooperated or, on the contrary, by authorizing further coercive measures, possibly including the use of force, in order to impose a definitive solution to the dispute).

3. On this issue, a reasonable approach would consist in harmonizing the timelines concerned (as the joint memorandum tried to do), while giving preference, in case of discrepancy, to Resolution I44I as the most recent (and unanimous) UNSC decision on the matter.

4. At any rate, a new decision by the UNSC was necessary, as neither Resolution 1284 nor Resolution I44I contained an automatic trigger for the application of their respective schemes to ensure the disarmament of Iraq's WMDs and each called for explicit UNSC decisions at key stages of their implementation.

\section{A FRUSTRATING OUTCOME}

In the end, then, the AJI did manage, in a roundabout way, to give the legal opinion that it had been prevented from providing several months before: in our considered opinion, the adoption of UNSC Resolution I44I did not change our previous conclusions concerning the international legal rules applicable to the situation, as that resolution did not in itself contain an authorization under Chapter VII of the UN Charter to use force in order to coerce Iraq to comply with its disarmament obligations. This is why a new, explicit decision by the UNSC was necessary to legally enable that course of action. Of course, that was precisely the implied rationale for the US-led draft resolution. Nevertheless, as is well known, that draft was not put to a vote by its co-sponsors, as it never gained sufficient support within the UNSC, a failure that did not prevent a US-led "coalition of the willing" from issuing an ultimatum to Saddam Hussein on 16 March and then launching large-scale military operations against Iraq on 19 March 2003, thereby completely by-passing the UN at that critical juncture.

It was by now evident that the Spanish government had not paid any attention to the AJI's arguments or even considered them. After having co-sponsored the ill-fated US-led draft resolution in the UNSC - which was openly backed only by a fourth Council member, Bulgaria - the then Spanish government joined in the "coalition of the willing" and enthusiastically supported both the ultimatum to the Iraqi regime and the launching of the military attack. Under those circumstances, I had made up my mind to resign from my position as Head of the Foreign Ministry's International Legal Office. However, something happened on the very day when the Spanish media reported on the US-led 
invasion of Iraq. One of the foremost Spanish newspapers, El Pais, also published a summary of the first AJI opinion on the matter, highlighting the fact that the Foreign Ministry's own legal advisers had internally argued that such a move would be an illegal course of action in the absence of an explicit UNSC authorization. Obviously, our report had somehow been leaked, and if I had resigned at that moment, all fingers would have pointed to me or the AJI as the most likely source. While that was certainly not the case, I felt duty-bound to stay on in order to protect my name and that of the AJI, as I was quite convinced that the leak did not originate in our Office. An internal investigation was launched at the Ministry, and I, among others, was questioned by the person in charge of the inquiry. The fact is that both the AJI and its head came out of the investigation free of any suspicion of having been the source of the leak.

Still, I remained at the AJI internally torn by what had happened and deeply unhappy at the turn of events. Even though I had been cleared of any suspicion of leaking an important AJI report, I privately vowed not to stay one day more in the Office if there were any attempt by my superiors to enjoin the AJI to prepare any after-the-fact legal justification for a government policy with whose legal foundation I was in profound disagreement. I imagine that the Ministry's principals must have picked up on this attitude of mine, because no request of that kind was ever received by the AJI. Whatever explanations or purported justifications for such actions were expounded by government officials or spokesmen in Parliament or at the UN must have been prepared by other Foreign Ministry units - or maybe elsewhere in the Administration - and basically consisted of barely disguised summaries of the arguments being used by the US or UK in similar circumstances at the time.

\section{SOME CONCLUSIONS AND REFLECTIONS}

I. This particular experience casts a harsh light on the peculiar position in which a Foreign Ministry's international legal office may find itself in trying to provide considered and solidly founded advice in a framework of difficult political constraints, especially on the eve or in the midst of an international crisis calling for tough decisions.

2. Normally, it is to be expected that the principal legal adviser in the Ministry would be consulted at each important stage of the development of such a crisis and, as far as possible, be involved in key discussions in which important choices touching on international legal matters are to be considered. However, in this particular case, the AJI's exclusion from those processes worked in its favour by protecting its independence of criterion from political interference.

3. The crucial moment for a legal adviser in such a situation is reached when his or her advice on a matter of principle is completely disregarded by the political decision-makers, especially if it concerns questions of war and peace. In such a case, that person may well come to the conclusion that the most honourable option would be to resign, all the more so should the political level try to extract a position contrary to his or her deeply held convictions.

4. In this particular case, the firm position taken by the Spanish Foreign Ministry's International Legal Office was ultimately vindicated, with regard to both the process (as it proved able to "speak 
truth to power" and was later cleared of any suspicion of leaking an internal report) and the substance (if one takes into account that few people would doubt today that the Iraq war was launched on false pretences and on very feeble, if any, legal grounds).

5. This case also shows the desirability of holding a public investigation on the decision-making process leading up to the Spanish involvement in the Iraq war, in order to draw lessons for the future (as is being done in the UK, with the Chilcot Inquiry).

Finally, one can only hope - sadly, against past experience- that what happened with the Iraq War and its tragic and deplorable consequences will push governments to better heed the considered opinion of their own legal advisers on these crucial matters. 